\title{
Rho GTPase-Activating Protein 5
}

National Cancer Institute

\section{Source}

National Cancer Institute. Rho GTPase-Activating Protein 5. NCI Thesaurus. Code C97281.

Rho GT Pase-activating protein 5 (1502 aa, $\sim 172 \mathrm{kDa}$ ) is encoded by the human ARHGAP5 gene. This protein is involved in GT Pase activity regulation. 